\title{
SEJARAH LIMBO TOMOAHI DALAM SISTEM PEMERINTAHAN BARATA KULISUSU (1605-1956) ${ }^{1}$
}

\author{
Oleh \\ Asmar $^{2}$, H. Barlian ${ }^{3}$
}

\begin{abstract}
ABSTRAK: Tujuan utama penelitian ini adalah: 1) Untuk menjelaskan latar belakang terbentuknya Limbo Tomoahi dalam sistem Pemerintahan Barata Kulisusu 1605-1956, 2) Untuk mendeskripsikan faktor-faktor Pembentukan Limbo Tomoahi Dalam sistem Pemerintahan Barata Kulisusu 1605-1956, 3) Untuk menjelaskan perkembangan Limbo Tomoahi Dalam sistem Pemerintahan Barata Kulisusu dari tahun 1605-1956.

Metode yang digunakan dalam penelitian ini adalah metode penelitian sejarah dengan langkah-langkah sebagai berikut: 1) pengumpulan sumber (heuristik) yaitu, kegiatan peneliti untuk memperoleh data; 2) kritik sumber (verifikasi) yaitu, untuk mengetahui otentitas (keaslian) dan kredibilitas (kebenaran) data yang berhasil dikumpulkan; 3) Penulisan sejarah (historiografi) yaitu, menyampaikan sintesis dalam bentuk kisah sejarah dalam 3 tahap, yaitu interpretasi (penafsiran), eksplanasi (penjelasan), dan ekspose (penyajian).

Hasil penelitian menunjukan bahwa: Latar Belakang Terbentuknya Limbo Tomoahi dilihat dari beberapa faktor yaitu: (a) Faktor wilayah, (b) Faktor sosial budaya, (c) Faktor pertanian. Faktor terbentuknya Limbo Tomoahi dalam sistem pemerintahan Barata Kulisusu ialah: Proses awal pembentukan limbo Tomoahi dari musyawarah kepala adat dan para tokoh-tokoh masyarakat yang berinisiatif untuk membentuk sebuah Limbo karena melihat pertumbuhan penduduk yang begitu pesat dan persyaratan pembentukan salah satu Limbo sudah sepenuhnya dimiliki oleh Tomoahi pada saat itu seperti jumlah penduduk, luas wilayah, sosial budaya, dan kehidupan masyarakatnya, sehingga tidak bisa dipungkiri, bahwasanya Limbo Tomoahi sudah layak dibentuk. Ini semua berkat antusiasme kepala kampung dan tokoh-tokoh masyarakat.

Perkembangan Limbo Tomoahi dalam pemerintahan Lakino Kulisusu Tahun 1605-1956 secara umum menunjukan perkembangan yang lebih baik seperti dalam bidang politik Limbo Tomoahi menunjukan pemerintahan yang sudah cukup maju seperti penyusunan hukum-hukum yang berlaku tentang pengangkatan aparat. Dalam bidang ekonomi masyarakat Limbo Tomoahi semakin maju ke arah kesejahteraan dengan memanfaatkan sumber daya alam dan sumber daya manusia dalam mengelola perkebunan. Dalam bidang sosial Limbo Tomoahi selalu menjunjung tinggi rasa kebersamaan dalam setiap kegiatan baik itu pembukaan lahan ataupun dalam upacara kematian. Selanjutnya, perpindahan wilayah dari Tangkeno Tomoahi ke Epe membuat Limbo Tomoahi menjadi semakin dekat dengan pusat pemerintahan Barata Kulisusu yang membuat Limbo Tomoahi dapat berhubungan secara langsung dengan pusat pemerintahan.
\end{abstract}

\section{Kata kunci: Pemerintahan, Limbo, Lakino Kulisusu}

\section{PENDAHULUAN}

Buton Utara merupakan salah satu kabupaten yang berada di Sulawesi Tenggara yang masih menyimpan banyak misteri sejarah dan belum banyak terjamah oleh berbagai penelitian. Berbagai situs sejarah dapat dilihat di daerah ini seperti benteng peninggalan dalam periode kerajaan, struktur pemerintahan, struktur kelembagaan adat, dan berbagai cerita rakyat yang menjelaskan keberadaan kehidupan masa lampau yang berkaitan dengan situs-situs sejarah yang masih bisa diamati di Buton Utara.

Sejarah perkampungan di kepulauan Buton amat beraneka ragam. Ada yang tumbuh secara evolusi dari pemukiman keluarga yang saling mempunyai tali hubungan darah (lewat perkawinan)

\footnotetext{
${ }^{1}$ Disandur dari hasil Penelitian

${ }^{2}$ Alumni Jurusan Pendidikan Sejarah

${ }^{3}$ Dosen FKIP
} 
atau genealogis maupun karena kedekatan tempat tinggal territorial. Namun sering pula ditemukan suatu perkampungan yang tumbuh tiba-tiba. Selain itu, ada pula perkampungan yang lahir karena pemerintah atau organisasi lain yang direstui pemerintah yang memerlukan lahan atau lokasi pemukiman mereka untuk dijadikan suatu obyek untuk kepentingan yang lebih luas seperti untuk kepentingan pembangunan.

Sartono Kartodirdjo (2002: 89) membagi sejarah menjadi dua yaitu: sejarah dalam arti objektif yang merupakan kejadian atau peristiwa yang tidak dapat terulang kembali, dan sejarah dalam arti subjektif atau suatu konstruksi (bangunan) yang disusun oleh penulis sebagai suatu uraian cerita (kisah). Kisah tersebut merupakan suatu kesatuan rangkaian dari fakta-fakta yang saling berkaitan. Pada dasarnya suatu ilmu tidak dapat berdiri sendiri melainkan saling berkaitan antara satu sama lain. Ilmu sejarah misalnya untuk mengetahui perkembangan ilmu-ilmu pengetahuan yang lain sangat membutuhkan ilmu sejarah, kerena fungsi ilmu sejarah adalah upaya penelusuran jejak-jejak masa lampau sehingga yang ada sekarang menjadi jelas. Menurut Rustam E. Tamburaka (1993: 5) bahwa sejarah adalah catatan tentang masyarakat umat manusia atau peradaban dunia tentang perubahan yang terjadi pada waktu manusia itu seperti: keliaran, keramahtamahan dan solidaritas golongan ini kian mencapai kehidupannya maupun dalam bermacam-macam ilmu pengetahuan dan pada umumnya tentang segala perubahan yang terjadi di dalam masyarakat karena watak itu sendiri.

Sejalan dengan itu, menurut Kuntowijoyo (2008: 210) bahwa "sejarah adalah ilmu yang mandiri". Mandiri artinya mempunyai filsafat ilmu sendiri, permasaalahan sendiri, dan penjelasan sendiri, yang dimana sejarah menafsirkan, memahami dan mengerti. Ada tiga hal yang harus dipahami dalam sejarah yaitu: (1) Penjelasan sejarah adalah hermeneutics dan verstehen, menafsirkan dan mengerti; (2) Penjelasan sejarah adalah penjelasan tentang waktu yang memanjang; (3) Penjelasan sejarah adalah penjelasan tentang peristiwa tunggal.

Limbo pertama kali muncul pada masa pemenintahan Tua Rade atau Raja IV untuk pertama kali Tobelo melakukan serangan ke Buton. Sasaran utama dalam serangan ini adalah daerah-daerah pesisir, utamanya Siompu dan Kadatua. Rakyat kedua daerah ini menyelamatkan diri dari marabahaya dengan cara meminta perlindungan di Keraton Buton. Orang-orang yang melarikan diri mendapat perlindungan dari raja dan diberikan tempat pemukiman di Keraton Buton. Perkampungan-perkampungan itu kemudian dikenal dengan nama Limbo Sambali, Limbo Melai, Limbo Rakia, Limbo Gama, Limbo Wandailolo. Seluruh kekuatan kerajaan bersatu padu menumpas bajak laut tersebut melalui pertempuran yang sengit. Penamaan limbo (kampung) tersebut masing-masing mengandung pengertian tersendiri sesuai peristiwa yang terjadi pada saat itu. Limbo Sambali artinya kampung luar (limbo=kampung; sambali=Luar). Dinamakan demikian karena bajak laut datangnya dari luar. Limbo Melai artinya kampung mulai (melai=mulai), artinya bajak laut mulai menggempur Buton. Limbo Rakia artinya kampung bagian (turakia=bagian) artinya bahwa orang-orang yang ada di Siompu dan Kadatua adalah bagian dari Wolio (Buton) karena itu harus dibela. Limbo Gama artinya kampung gema (goma=gema), artinya bahwa peristiwa yang menggemparkan tersebut menggema di seluruh penjuru kerajaan. Limbo Wandailolo artinya kampung angin laut (wondailolo=angin laut) mengingatkan bahwa peristiwa tersebut datangnya dari arah laut, diantar oleh angin laut (La Ode Zaenu, 1990 dalam Amasa, 1991: 45). Dalam pertempuran tersebut para bajak laut dapat ditaklukan oleh pasukan Buton.

Terbentuknya suatu Limbo dapat disebabkan karena dalam Limbo tersebut ada hubungan teritorial yang sama dan berdekatan. Adanya tujuan khusus yang berkaitan erat dengan aktifitas sehari-hari dan adanya ikatan keagamaan yang selalu mempersatukan umatnya serta adanya aturan yang datang dari atas misalnya batas dari suatu Limbo dengan Limbo lainnya yang diatur dalam undang-undang pemerintahan. Menurut Suparto (1987: 13) bahwa masyarakat adalah kumpulan individu-individu yang telah lama tinggal dalam suatu daerah dan mempunyai aturan-aturan menuju kepada tujuan yang sama. Dalam ilmu kemasyarakatan (sosiologi) kita mengenal ada dua masyarakat, yaitu masyarakat paguyuban dan masyarakat patembayan. Dalam masyarakat paguyuban (gemein chaft) terdapat suatu hubungan pribadi antara anggoto-anggota yang menimbulkan suatu ikatan batin antara mereka. Dalam masyarakat petembayan (gesel schaft) 
terdapat hubungan pamrih antara anggota-anggotanya, suatu hubungan yang terutama ditujukan untuk memperoleh keuntungan kebendaan. Misalnya perkumpulan dagang, kehidupan dalam perusahaan koperasi-koperasi dalam (Hidayat, 2016: 19).

Buton Utara merupakan wilayah bekas Barata Kesultanan Buton yang dulunya bernama Barata Kulisusu. Istilah "Barata" mengandaikan filosofi pemerintahan Kesultanan Buton yang mengandaikan negara sebagai sebuah perahu bercadik. Seperti dapat diketahui bahwa perahu bercadik ditopang oleh dua penyangga di bagian kiri dan kanan kapal yang berjumlah empat penyangga. Penyangga perahu ini disebut Barata Patapalena (barata yang empat) dalam sistem pemerintahan Kesultanan Buton. Keempat barata itu adalah Barata Muna, Kulisusu, Tiworo dan Kaledupa.

Perubahan sosial juga menyangkut faktor-faktor penyebab terjadinya proses perubahan. Faktorfaktor penyebabnya bisa bersifat internal maupun eksternal. Adapun faktor internal dan eksternalnya sebagai berikut:

1. Faktor internal, yaitu pertambahan dan penyusutan jumlah penduduk, penemuan-penemuan baru, konflik ataupun pemberontakan yang terjadi dalam masyarakat itu sendiri.

2. Faktor eksternal, yaitu peristiwa-peristiwa fisik (bencana-bencana alam yang besar), peperangan, dan kontak dengan pengaruh dari kebiasaan lain (Soerjono Soekanto (2006: 321)

Perubahan sosial selalu diikuti dengan adanya perubahan kebudayaan masyarakat, sebab antar kebudayaan dan masyarakat tidak dapat dipisahkan sehingga apa saja yang dialami masyarakat dapat berpengaruh terhadap unsur-unsur kebudayaan. Proses perubahan sosial dalam suatu masyarakat baik masyarakat pendatang maupun masyarakat lokal pasti mengalami perubahan.

Buton Utara yang dikenal sekarang adalah bekas wilayah Barata Kulisusu yang termasuk dalam empat negara penyangga pemerintahan Kesultanan Buton. Barata Kulisusu merupakan wilayah yang berada di bawah administrasi pemerintahan Kesultanan Buton. Selanjutnya dalam Barata Kulisusu terdapat satuan pemerintahan terendah yang disebut Limbo. Dengan demikian Limbo adalah satuan pemerintahan terendah di bawah pemerintahan Barata. Satuan Limbo adalah satuan pemerintahan yang diberikan hak otonomi adat sehingga merupakan badan hukum. Dengan keadaan seperti ini, maka keberadaan Limbo baik sebagai lembaga pemerintahan maupun sebagai identitas kesatuan masyarakat hukum menjadi sangat penting dan strategis. Sebagai lembaga pemerintahan, Limbo merupakan ujung tombak pemberian layanan kepada masyarakat. Kemudian sebagai identitas kesatuan masyarakat hukum, Limbo merupakan basis sistem kemasyarakatan yang kokoh sehingga dapat menjadi landasan yang kuat bagi pengembangan sistem politik, ekonomi, sosial budaya, dan bahkan menjadi stabil dan dinamis.

Banyak masyarakat yang tidak memahami atau mengetahui tentang pentingnya sejarah Limbo Tomoahi dalam pemerintahan Lakino Kulisusu. Hal ini dikarenakan minimnya pengetahuan tentang sejarah Limbo itu sendiri, misalnya sumber untuk mengetahui sejarah di wilayahnya sangat sedikit, karena kebanyakan saksi sejarahnya sudah meninggal dan bahkan sumber informan yang masih hidup sudah mulai pikun atau bukan penduduk asli wilayah tersebut, dan lain sebagainya.

\section{METODE PENELITIAN}

Tempat atau lokasi penelitian adalah di Desa Tomoahi Kecamatan Kulisusu Kabupaten Buton Utara. Dengan menggunakan jenis penelitian sejarah yang bersifat deskriptif kualitatif, dan pendekatan strukturis. Sumber data penelitian terdiri atas (1) Sumber tertulis, (2) Sumber lisan. Prosedur penelitian metode sejarah yang menurut Helius Sjamsuddin (2012) yang terdiri atas 3 (tiga) yaitu: Pertama Heuristik yang terdiri dari (a) penelitian kepustakaan (library research), penelitian lapangan (field research), yang dilakukan dengan cara pengamatan (observasi), wawancara (interview), studi dokumen. Kedua Verifikasi (Kritik Sumber) yang terdiri atas dua yakni kritik eksternal dan Kritik Internal. Tahapan ketiga adalah historiografi yang terdiri atas interprestasi (penafsiran), eksplanasi (penjelasan) dan ekspose (penyajian). 


\section{HASIL PENELITIAN DAN PEMBAHASAN \\ Latar Belakang Terbentuknya Limbo Tomoahi Dalam Sistem Pemerintahan Barata Kulisusu}

Limbo Tomoahi adalah salah satu Limbo yang terdapat di Barata Kulisusu yang dibentuk oleh Lakina Kulisusu setelah terintegrasi dalam Kesultanan Buton Proses integrasi Kulisusu dalam Kesultanan Buton terjadi pada awal abad ke-17 (1613) bersamaan dengan penetapan Murtabat Tujuh sebagai undang-undang kesultanan Buton. Bermula dari kunjungan Sultan Buton ke-4 La Elangi atau Sultan Dayanu Iksanudin ke wilayah Buton Utara dalam rangka syiar Islam dan kemudian menikahi Wa Bilahi putri Lakina Lemo. Pernikahan itu dianugerahi seorang Putra yang bernama La Ode-Ode yang kemudian menjadi Lakina Kulisusu pertama. Sehingga proses integrasi Buton Utara kedalam barata Kesultanan Buton terjadi karena adanya hubungan keluarga yakni hubungan ayah dan anak. Dalam penelitian ini mengapa masih perlu penjelasan tentang Buton Utara setelah terintegrasi dengan Kesultanan Buton karena dengan pertimbangan bahwa Buton Utara pada masa prabarata baru berdiri satu pemerintahan yang terstruktur setelah terintegrasi dengan Kesultananan Buton yakni dengan terbentuknya Barata Kulisusu. Dalam masa ini, dengan adanya ancaman dari arah "buritan" maupun dari "haluan", sebagaiman digambarkan tradisi lokal, mencerminkan analogi negara Buton (Darul Butuni) dengan sebuah perahu (the ship of state) tradisi lokal menyebutkan bahwa penyusunan birokrasi Kesultanan Buton dilakukan pada masa Sultan La Elangi. (waktu itu pula, perluasan pengaruh Ternate dan Gowa dilakukan keluar wilayahnya). Ada hubungan perluasan antara pengaruh Ternate dan Gowa dengan penerapan struktur kekuasaan Buton bagi wilayah-wilayah yang di kendalikannya the ship of state Buton dalam penerapannya adalah Barata, perahu bercadik ganda. Dalam konteks itu, dapat dipahami munculnya gagasan bahwa konsepsi mengenai kerajaan Buton diambil dari struktur perahu. Perahu dianggap dapat membawa seluruh penumpang warga negara berlayar menuju cita-cita yang diharapkan (Zuhdi, 2010:120).

Layaknya sebuah perahu yang mempunyai keseimbangan sehingga tidak mudah goyang apalagi sampai terbalik. Konsepsi perahu yang dibayangkan Kerajaan Buton adalah perahu bercadik ganda, yang mempunyai dua sayap di kanan dan dua sayap di kiri. Pada setiap pertemuan dua sayap dan pengapitnya ada ikatan berfungsi sebagai penguat. Ke empat penguat disebut barata. Dalam bahasa Wolio, barata selain berarti "tenaga" atau "kekuatan" juga berarti ikatan pasak pengapung sayap perahu dengan tangannya. Barata yang dimaksud dengan penopang kesultanan Buton adalah Muna, Tiworo, Kulisusu, dan Kaledupa. (Zuhdi, 2010:120). Ke empat barata itu dinamakan barata patapalena artinya barata yang ke empat. Antara Buton dan daerah barata tersebut saling bantu membantu dalam segala hal demi kepentingan bersama, terutama dalam bidang pertahanan dan keamanan. Sebelum terintegrasi dengan Kesultanan Buton, Buton Utara merupakan wilayah yang terdiri dari berbagai komunitas pemukiman kecil yakni Doule, Bangkudu, dan Lemo. Dari ketiga pemukiman ini diperintah oleh seorang Sangiano, dimana Sangiano menurut sumber dari Informan diidentikkan dengan orang yang sangat berani, kuat, sakti dan memiliki kekuatan magic. Beberapa komunitas ini belum memiliki inisiatif atau belum memiliki kontrak sosial untuk bersatu membentuk sebuah kerajaan atau lipu (negeri). Namun antara ketiga komunitas pemukiman tersebut bukan tanpa hubungan.

Model hubungan antara Doule, Bangkudu dan Lemo bagaikan ular, kepala adalah Doule, tengahnya adalah Bangkudu dan ekornya adalah Lemo. Sangia Doule dianggap kepala karena lebih kuat, lebih sakti, kemudian Bangkudu dan terakhir Lemo. Jika Lemo tidak bisa menyelesaikan masalah yang terjadi diwilyahnya, maka Sangia Lemo wajib melapor ke Bangkudu dan Bangkudu melaporkannya ke Sangia Doule (Adnan, wawancara 24 Oktober 2018).

Setelah di jadikan sebagai Limbo Tomoahi pada tahun 1605 dengan Laode Rasim sebagai Lakino Tomoahi pertama yang di lantik oleh Laode ode sebagai Lakino Kulisusu pertama dengan pusat pemerintahan di Tangkeno Tomoahi dan lama pemerintahan seumur hidup. Ia berhasil mendirikan benteng Tomoahi yang berlokasi di Tangkeno Tomoahi yang menjadikan perlindungan bagi penduduk Tomoahi dari berbagai gangguan baik gangguan orang maupun gangguan hewan buas, benteng ini mempunyai tiga pintu masuk (lawa) yaitu lawa Opa-opa, lawa Kadudia saat ini 
masuk wilayah Tabunculi, lawa Empayasa setelah Laode Rasim mangkat dari jabatannya ia kemudian digantiakan oleh Laode Camba sebagai Lakino Tomoahi kedua dan setelah masa kepemimpinannya ia di gantikan oleh Laode Cabo yang memindahkan lokasi Limbo Tomoahi yang semula berda di Tangkeno Tomoahi berpindah ke Epe.

Nama Tomoahi diambil dari nama sebuah bukit yakni bukit Tomoahi dimana bukit Tomoahi ini ditemukan oleh Sangiano Doule (penguasa) pada saat itu, Sangiano Doule sedang berjalan berburu babi hutan kemudian bertemu dengan 4 (empat) orang berada dibawah pohon Ahi saat itu, keempat orang tersebut sedang memakan buah Ahi, maka dari itu kemudian Sangiano Doule menyebut kawasan tersebut dengan nama Tomoahi. Sebelum Limbo Tomoahi terbentuk wilayah Tomoahi masuk dalam wilayah kekuasaan Sangiano Doule

Adapun uraian latar belakang terbentuknya Limbo Tomoahi adalah sebagai berikut:

a. Faktor Wilayah

Dukungan wilayah dalam rangka pelaksanaan pemerintahan baik ditingkat kesultanan, barata, maupun tingkat Limbo atau kampung merupakan suatu hal yang sangat penting. Demikian pula halnya dengan latar belakang terbentuknya Limbo Tomoahi dengan kondisi wilayah beserta potensi yang ada di dalamnya karena pertimbangan yang cukup strategis sehingga memungkinkan berhubungan antara Limbo Tomoahi dan pemerintah Barata bahkan dengan pemerintah kesultanan yang dimana tadinya hanya sebuah pemungkiman yang kemudian menjadi sebuah Limbo. Limbo mencakup wilayah yang cukup luas berbatasan lansung dengan Limbo-Limbo yang ada di sekitarnya yakni sebelah utara berbatasan dengan Limbo Mata oleo dan disebelah selatan berbatasan dengan Limbo Kalibu (Adnan wawancara 24 Oktober 2018).

Limbo Tomoahi sebenarnya mencakup tiga pemungkiman yakni pemungkiman Jampaka, Tomoahi dan Kampo baru yang dimana ketiga wilayah ini masuk dalam wilayah Limbo Tomoahi dengan ibukota pemerintahan berada di Tomoahi, pemungkiman Jampaka berada di sebelah selatan Tomoahi sedangkan Kampo baru berada di sebelah utara Tomoahi hal ini juga yang menjadi ibukota pemerintahan dengan alasan wilayah Tomoahi berada di tengah dari ketiga pemungkiman sehingga apabila ada keperluan maka akan lebih mudah di jangkauh, selain itu Tomoahi juga merupakan wilayah yang lebih maju dari dan ramai dari ketiga wilayah pemungkiman (La Siri wawancara tanggal 26 Oktober 2018).

Faktor wilayah merupakan salah satu faktor penyebab terbentuknya Limbo Tomoahi dimana luas wilayah akan mempengaruhi proses perkembangan Limbo, semakin sempit luas wilayah suatu daerah maka akan membuat masyarakat yang bermungkim didalamnya kesulitan baik dalam hal berkebun maupun dalam hal pembangunan tempat tinggal, selain itu luas wilayah merupakan penanda antara Limbo Tomoahi yang satu dengan Limbo yang lain karena dari luas wilayah inilah akan ditetapkan batas batas wilayah suatu Limbo.

b. Faktor Sosial Budaya

Sosial budaya merupakan faktor pendukung pembentukan suatu Limbo melalui kegiatan pembangunan dalam bidang sosial budaya diharapkan antara masyarakat yang ada di Limbo Tomoahi maupun pemeritah terjalin hubungan yang harmonis, hormat-menghormati, guna dalam menciptakan suasana yang harmonis dan kondusif sehingga dapat meningkatkan taraf hidup dan kesejahteraan masyarakat yang ada di Limbo Tomoahi. Kegiatan pembangunan dalam bidang sosial di Limbo Tomoahi sudah terwujud sebelum Limbo Tomoahi definitif, pembangunan yang dimaksud seperti melalui saluran-saluran organisasi sosial. Organisasi sosial tersebut dimaksudkan sebagai wadah untuk menghimpun para warga masyarakat seluruh potensi yang dimiliki oleh daerah setempat, sehingga dikenal dengan sistem budaya mekatambani (saling membantu) yang masih tetap terwujud kelestariannya hingga sekarang ini, yang diwujudkan dalam bentuk kerja sama, baik antara pemerintah maupun sesama anggota masyarakat setempat yang saling mendukung dalam perjuangan pembentukan Limbo Tomoahi. Sistem budaya mekatambani (saling membantu) ini sering dilakukan jika ada kegiatan-kegiatan apa saja dalam lingkup Limbo maupun sesama masyarakat sendiri, sehingga terwujud hubungan timbal balik yang harmonis dalam lingkup Limbo Tomoahi. Kemudian Limbo Tomoahi memiliki nilai budaya yang sangat tinggi. Budaya juga merupakan faktor pendukung terbentuknya suatu Limbo dimana masyarakat setempat memiliki 
kekerabatan yang sangat menonjol dan tidak akan hilang sampai sekarang. Sistem kekerabatan ini masih dipegang teguh oleh masyarakat dan nilai-nilai budaya sangat dihormati dan dijunjung tinggi oleh masyarakat Limbo Tomoahi, misalnya dalam memperingati hari-hari besar keagamaan dan ritual-ritual adat lainnya.

Beberapa sumber lain menurut hasil cerita rakyat yang diperoleh menjelaskan bahwa penampakan dari wujud rasa sosial masyarakat Limbo Tomoahi pada masa dulu, akan sangat dirasakan ketika keluarga yang mengadakan acara perkawinan, berasal dari keluarga yang sangat kurang, maka semua kalangan baik sebagai pemimpinnya pemukiman, Sangia, maupun dari kalangan rakyat akan turut membantu demi suksesnya acara. Bantuan-bantuan yang diberikan kepada keluarga tergantung dari apa yang mereka miliki, kalau tidak ada barang yang diberikan maka akan membantu dengan tenaganya.

Adapun sumber dari hasil informasi peneliti sangat tampak ketika ada keluarga yang berduka, maka semua masyarakat akan turut mengulurkan tangan, memberikan bantuan yang dimiliki untuk keluarga yang terkena musibah. Modelnya bukan hanya keluarganya yang ditimpa musibah yang akan dibantu, akan tetapi masyarakat secara umum, pada saat seperti ini sangat tampak rasa solidaritasnya. Rasa solidaritas sebagai wujud rasa sosial masyarakat Tomoahi Pada Masa itu, Salah satu informan mengatakan bahwa:

Kehidupan sosial masyarakat Limbo Tomoahi, sangat tampak ketika masyarakat mengadakan aktivitas, baik itu pembukaan lahan pertanian, acara perkawinan, acara kedukaan, dan acara pesta panen. Pada saat itu saling memberi antara sesama, dan bekerja tanpa mengharapkan imbalan jasa. Model dari wujud rasa solidaritas dalam keseharian masyarakat Limbo Tomoahi pada masa lalu bukan hanya kalangan Sangia (pemimpin) yang akan merasa dihargai akan tetapi semua kalangan masyarakat pada umumnya mengutamakan rasa kebersamaan.

c. Faktor pertanian

Keadaan pertanian masyarakat Limbo Tomoahi merupakan dasar dalam pembangunan wilayah maupun pemasukan terhadap konstribusi pajak yang dibayarkan oleh masyarakat guna pembangunan di daerah ini. Usaha bidang pertanian dan perkebunan di wilayah ini merupakan indikator yang mendukung aspek ekonomi dalam pembentukan Limbo Tomoahi (La Uso, wawancara 25 Oktober 2018)

Hal serupa juga diungkapkan oleh La Siri yang mengatakan bahwa keadaan ekonomi merupakan syarat utama terbentuknya Limbo karena di hasil perekonomianlah yang merupakan faktor utama untuk membangun Limbo dan Tomoahi memiliki sumber daya dalam hal pertanian yang sangat baik yakni berupa padi, jagung, sayur-sayuran ubi kayu keladi dan lain sebagainya yang bisa menunjang kebutuhan hidup serta pendapatan ekonomi masyarakat dan Limbo itu sendiri (La Siri wawancara 26 Oktober 2018).

Pada saat Buton Utara terintegrasi dengan kesultanan Buton daerah ini baru mengenal alat tukar yakni "ringgit" hal ini berdasarkan hasil wawancara, di mana informan mengatakan bahwa masyarakat Buton Utara mengenal doi (uang) pada saat bersatunya dengan kerajan Kesultanan Buton, yang diperkenalkan oleh bangsa Belanda di Buton (La Uso wawancara tanggal 25 Oktober 2018). Pertanian merupakan faktor paling penting dalam pembangunan suatu daerah karena pertanian yang baik akan mempercepat proses perkembangan suatu daerah, faktor ekonomi yang baik bisa dilihat dari tingkat kesejahteraan masyarakat yang mendiami tempat tersebut. Limbo Tomoahi dilihat dari faktor ekonomi sangat baik karena kesejahteraan masyarakat Tomoahi sangat bagus hal ini karena lahan perkebunan yang subur dan pengolahan masyarakat yang sangat baik walaupun masih menggunakan cara tradisional.

Dukungan wilayah dalam rangka pelaksanaan pemerintah baik setiap kesultanan, barata, dan Limbo/kampung merupakan hak yang mutlak. Letak geografis yang dimiliki Limbo Tomoahi ini sangat strategis karena merupakan suatu tempat yang mudah berhubungan dengan wilayah Barata bahkan wilayah kesultanan karena jaraknya sangat terjangkau. Apalagi layanan transportasi lancar, sehingga memungkinkan mudahnya berhubungan dengan wilayah kesultanan yang bisa melalui jalur darat dan jalur laut. Untuk memenuhi kebutuhan hidup sehari-hari masyarakat di 
daerah ini sebagian besar menggantungkan hidupnya dibidang pertanian, nelayan maupun dibidang lainnya.

Daerah ini cukup potensial wilayah pembangunannya dalam rangka melaksanakan dan mendukung pembangunan di daerah ini. Wilayah ini bisa diperhatikan keadaan geografisnya yang sangat cocok untuk daerah pertanian dan perkebunan. Potensi ini diharapkan dapat menopang kehidupan masyarakat di Limbo Tomoahi (Adnan, wawancara, 24 Oktober 2018).

\section{Proses Terbentuknya Limbo Tomoahi Dalam Sistem Pemerintahan Barata Kulisusu}

Limbo Tomoahi merupakan salah satu Limbo yang dibentuk oleh Barata Kulisusu pada tahun 1605. Untuk mengetahui proses terbentuknya Limbo Tomoahi, berarti kita perlu melihat proses wilayah Tomoahi hal ini karena sebelum terbentuknya Limbo telah terdapat pemungkiman yang dinamakan Tomoahi yang berlokasi di Tangkeno Tomoahi. Pada dasarnya proses terbentuknya Limbo Tomoahi hampir sama dengan pembentukan Limbo-Limbo lainnya, ada beberapa proses yang harus dilaluinya oleh Tomoahi sebelum menjadi sebuah Limbo.

Proses awal pembentukan Limbo Tomoahi tidak terlepas dari musyawarah kepala adat dan para tokoh-tokoh masyarakat yang berinisiatif untuk membentuk sebuah Limbo karena melihat pertumbuhan penduduk yang begitu pesat dan persyaratan pembentukan salah satu Limbo sudah sepenuhnya dimiliki oleh Tomoahi pada saat itu seperti jumlah penduduk, luas wilayah, sosial budaya dan kehidupan masyarakatnya. Sehingga tidak bisa dipungkiri, bahwasanya Limbo Tomoahi sudah layak dibentuk. Ini semua berkat antusiasme tokoh-tokoh masyarakat dan kepala adat serta dukungan dari Barata Kulisusu. Mula-mula yang dilakukan oleh kepala adat (Rasim) yaitu menghimpun para tokoh-tokoh masyrakat untuk segera membicarakan proses pembentukan Limbo Tomoahi. Masing-masing masyarakat mempunyai wilayah pemukiman yang berbeda-beda. Hal ini dilakukan semata-mata untuk mengajak masyarakat agar ikut mendukung terbentuknya satu Limbo yaitu Limbo Tomoahi yang bisa mempunyai hak otonomi untuk mengurus masyaraktnya sendiri.

Setelah mendapatkan dukungan dari masyarakat Tomoahi pada saat itu, barulah diadakan koordinasi kepada pemerintah Barata, dalam hal ini Lembaga Sara untuk segera mengusulkan kepada pemerintah Lakino Kulisusu dalam pembentukan Limbo tersebut. Setelah berjuang bersama-sama dalam pembentukan Limbo Tomoahi selama beberapa bulan maka tahun 1605 tibalah saat yang dirindukan seluruh masyarakat Tomoahi. Dengan terbentuknya Limbo Tomoahi maka sudah mulai direncanakan tentang program-program pembangunan. Hal pertama yang dilakukan Lakino Tomoahi bersama dengan tokoh-tokoh masyarakat mengadakan rapat membahas batas-batas wilayah Limbo. Adapun batas wilayah Limbo Tomoahi pada saat itu, terbentang dari utara ke selatan yakni sebelah utara berbatasan dengan Limbo Mataoleo dan sebelah selatan berbatasan dengan Limbo Kalibu (Adnan, wawancara 24 Oktober 2018).

\section{Perkembangan Limbo Tomoahi Dalam Sistem Pemerintahan Barata Kulisusu Tahun 1605-1956 1. Perkembangan Politik}

Lakino Tomoahi merupakan seorangpemimpin yang memegang tambuk kekuasaan bersama dengan seorang walaka yang secara bersama-sama memikul tanggung jawab terbatas untuk menggunakan kekuasaan, Limbo Tomoahi dipimpin pertama kali dipimpin oleh Laode Rasim pada tahun 1605, setelah dilantik oleh Laode Ode sebagai Lakino Kulisusu kemudian di gantikan oleh Laode Camba dan yang terakhir adalah Laode Cabo. Lama masa kepemimpinan berlangsung selama masih hidupnya. Dalam perkembangan politik Limbo Tomoahi diawali dengan banyaknya penduduk yang mendiami wilayah Tomoahi dan pembentukan ini merupakan sebuah perintah dari penguasa setempat, disusul pemilihan dan penetapan Lakino yang harus memimpin satu Limbo. Setelah adanya Lakino maka dimulailah pelaksanaan pemerintah yang mempunyai hak otonomi dan seterusnya. Dalam bidang politik Limbo Tomoahi terlihat dari penyususunan hukum yang berlaku seperti pembayaran pajak yang di bebankan kepada setiap warga Limbo Tomoahi dalam sistem pembayaran berupa hasil alam seperti padi, jagung, umbi-umbian dan lain sebagainya. 
Selain itu, pengangkatan aparat pemerintahan dalam hal ini Walaka sebagai pembantu Lakino Tomoahi dalam menjalankan tugasnya (Adnan, wawancara 24 Oktober 2018).

Pejabat Limbo dipilih dan diangkat dari Limbo itu sendiri namun atas persetujuan Barata Kulisusu. Pada saat-saat tertentu jabatan Lakina dapat diambil alih oleh penguasa pusat dalam rangka pengamanan wilayah, namun bila keadaan mulai stabil maka jabatan tersebut diserahkan kembali pada Limbo. Perkembangan politik di Limbo Tomoahi jika dilihat dari awal terbentuknya dari tahun 1605 samapai 1956 maka sangatlah maju baik dalam hal pemerintahan maupun pengaturan tatanan hukum yang berlaku terbukti dengan aman dan tentramnya keadaan Limbo Tomoahi.

\section{Perkembangan Ekonomi}

Perkembangan ekonomi diperoleh berdasarkan hasil produksi dari daerah setempat biasannya masih bersifat tradisional. sumber pendapatan asli Limbo terdiri hasil perkebunan, hasil laut, ternak dan kerajinan tangan dalam masalah pembayaran pajak berupa hasil perkebunan yang disetor kepada pemerintah baik berupa padi, jagung sayur-sayuran dan lain-lain. Fungsi Limbo Tomoahi di bidang perekonomian dapat dilihat dan sistem perpajakan yang ditetapkan oleh Barata Kulisusu. Khusus wilayah Limbo-Limbo yang ada di Barata Kulisusu, termasuk Tomoahi pajak yang paling diutamakan adalah pajak perdagangan. Ketetapan pajak yang telah digariskan dalam Undang-Undang Barata tidak sama untuk setiap Limbo, tetap disesuaikan dengan penghasilan yang ada di tiap-tiap Limbo tersebut. Ketetapan pajak khususnya di bidang perdagangan biasa disebut dengan istilah Jawana Barata. Jawana Barata Kulisusu untuk setiap tahunnya adalah sebesar 45 boka (Adnan, wawancara 24 Oktober 2018).

Sebagian besar masyarakat Limbo Tomoahi menggantungkan hidupnya dibidang pertanian yang merupakan hasil budaya yang telah dilakukan dan dikembangkan secara turun temurun, apabila dilihat dari kondisi lingkungan alam dan penguasaan teknologi serta peralatan pertanian yang masih sederhana, maka dengan terjun dibidang pertanian memang sangat cocok untuk dipilih sebagai salah satu alternative pemenuhan hidup masyarakat karena keadaan alam yang subur.

Model awal proses perekonomian masyarakat Limbo Tomoahi pada masa lalu, dengan mekansaaru (meminjam) hasil panen pada orang lain maupun daerah lain untuk memenuhi kebutuhannya, hal ini dilakukan untuk mempertahankan kehidupannya, sambil menunggu daerahnya tiba masa panen, ketika daerahnya panen maka akan menggantinya sesuai dengan hasil pangan yang dipinjamnya misalnya padi-padian. model perekonomian masyarakat Limbo Tomoahi pada masa dahulu, dalam prosesnya hanya mengharapkan hasil panen, dari tanaman yang masyarakat tanam, ada kemukinan daerah yang satu berhasil panen ubi-ubian dan daerah lain berhasil panen padi-padian sehingga dari kedua model ini akan saling menukarkan barangnya (La Uso wawancara tanggal 25 Oktober 2018).

Pada saat Buton Utara terintegrasi dengan kesultanan Buton daerah ini baru mengenal alat tukar yakni "ringgit" hal ini berdasarkan hasil wawancara dengan informan yang mengatakan bahwa masyarakat Buton Utara mengenal doi (uang) pada saat bersatunya dengan kerajan Kesultanan Buton, yang diperkenalkan oleh bangsa Belanda di Buton yang kemudian dijadikan sebagai alat tukar yang sah di wilayah Barata Kulisusu oleh Lakina Kulisusu termasuk Limbo Tomoahi mulai menggunakan ringgit sebagai alat tukar yang sah pada saat itu (La Uso wawancara tanggal 25 Oktober 2018).

\section{Perkembangan Sosial}

Pada masyarakat Tomoahi sebelum terbentuk Limbo ataupun sudah terbentuk Limbo memiliki kehidupan social yang sangat baik dalam proses interaksi sesama masyarakat maupun interaksi dengan pemimpin (Sangiano). Masyarakat dalam hari-harinya Sangat mengedepankan rasa solidaritas yang tinggi ketimbang kepentingan pribadinya. Misalnya setelah panen hasil pertanian padi, maka akan mengadakan pesta panen sebagai wujud rasa sukur, maka semua masyrakat yang ada di pemukiman lain akan menghadiri pesta ini dan turun serta dalam membantu masyarakat pemukiman demi untuk terselenggaranya acara tersebut. Hal ini terjadi bukan hanya satu daerah tapi seluruh pemukiman yang ada di Buton Utara pada masa itu dan itu sangat nampak 
dalam acara apapun baik dalam rangka pembukaan lahan, acara perkawinan maupun pertunjukan acara-acara lain yang mencirikan kekhasan, seperti alionda. Alionda ini adalah pertunjukan masyarakat, sebagai satu pertunjukan yang sangat menarik disetiap acara-acara keramaian yang akan menghibur para penyelenggra acara maupun para pendatang dari pemukiman atau daerah lain.

Beberapa sumber lain menurut hasil cerita rakyat yang diperoleh menjelaskan bahwa penampakan dari wujud rasa sosial masyarakat akan sangat dirasakan ketika keluarga yang mengadakan acara perkawinan, berasal dari keluarga yang kurang mampu, maka semua kalangan baik sebagai pemimpin pemukiman, Sangia, maupun dari kalangan rakyat akan turut membantu demi suksesnya acara. Bantuan-bantuan yang diberikan kepada keluarga tergantung dari apa yang mereka miliki, kalau tidak ada barang yang diberikan maka akan membantu dengan tenaganya.

Adapun sumber dari hasil informan peneliti juga sangat tampak ketika ada keluarga yang berduka, maka semua masyarakat akan turut mengulurkan tangan, memberikan bantuan yang dimiliki untuk keluarga yang terkena musibah. Modelnya bukan hanya keluarganya yang ditimpa musibah yang akan dibantu, akan tetapi masyarakat secara umum, pada saat seperti ini sangat tampak akan rasa solidaritasnya. Rasa solidaritas sebagai wujud rasa sosialnya masyarakat sesuai salah satu informan mengatakan bahwa Kehidupan sosial masyarakat Buton Utara pada masa prabarata, sangat tampak ketika masyarakat mengadakan aktivitas, baik itu pembukaan lahan pertanian, acara perkawinan, acara kedukaan, dan acara pesta panen. Pada saat itu saling memberi antara sesama, dan bekerja tanpa mengharapkan imbalan jasa. (La Siri, wawancara 26 Oktober 2018).

Menurut La Uso bahwa Hal yang diutamakan pada masa itu adalah hal yang paling diutamakan dalam kehidupan keseharianya dalam bermasyakat saling memberi tanpa mengenal keluarga akan tetapi secara umum sesuai atas apa yang dimilikinya. Sedangkan menurut informan lain mengatakan bahwa Model dari wujud rasa solidaritas dalam keseharian masyarakat bukan hanya kalangan Sangia (pemimpin) yang akan merasa dihargai akan tetapi semua kalangan masyarakat pada umumnya mengutamakan rasa kebersamaan (La Uso, wawancara tanggal 25 Oktober 2018).

\section{Perpindahan lokasi Limbo Tomoahi}

Limbo Tomoahi merupakan salah satu Limbo yang berada di Barata Kulisusu dan merupakan wilayah yang berada di dalam kekuasaan kesultanan Buton. Limbo Tomoahi mengalami perpindahan tempat dari Tangkeno Tomoahi berpindah ke Epe karena di latarbelakangi oleh serangan Tobelo (Ternate) yang oleh masyarakat Tomoahi menyebutnya dengan gerombola (perpindahan berkelompok).

Meskipun Ternate menjadi sekutu bagi Buton akan tetapi Ternate sewaktu-waktu menjadi ancaman dan gangguan Buton selama beratus-ratus tahun. Susanto Zuhdi mengatakan bahwa di bawah komando VOC, Buton dan Ternate bersekutu melawan Gowa. Akan tetapi pada waktu yang lain, keduanya berseteru. Ternate selalu berusaha menganeksasi Kulisusu dan Pulau Wawoni yang dianggapnya sebagai wilayah bagian utara kekuasaan Buton keadaan berlansung hingga abad ke-19 (Zuhdi, 2010: 11).

Akibat dari serangan Tobelo ini maka rakyat Limbo Tomoahi berpindah kedaerah lain guna melindungi diri dari Tobelo, rakyat Limbo Tomoahi sebagian besar berpindah ke Limbo Mataoleo, Limbo Kalibu, Wawonii (roko roko) dan daerah daerah lain yang berada di Barata Kulisusu ( La Siri, 26 oktober 2018). Serangan Tobelo berakhir sesudah penandatanganan Perjanjian Bungaya, Kapitan Laut Reti (Ternate) telah membawa orang Kulisusu ke Ternate pada tahun 1690. Persoalan yang menimbulkan konflik ini disebabkan oleh perbedaan kepentingan Buton dan Ternate. Bagi Buton, Kulisusu merupakan salah satu baratanya, sedangkan bagi Ternate orang Kulisusu dapat menambah penduduknya yang minim (Adnan, wawancara 24 Oktober2018).

Masyarakat Limbo Tomoahi kembali ke Tomoahi setelah Lasiri pulang dari Wawonii yang kemudian menemui masyarakat Tomoahi di berbagai daerah tempat mereka mengungsi guna membagun kembali Limbo Tomoahi. Akan tetapi masyarakat Tomoahi tidak ingin kembali jika Tomoahi masih tetap berada di Tangkeno Tomoahi maka dari itu Limbo Tomoahi dipindahkan ke 
Epe (La Siri, wawancara 26 Oktober 2018). Hal serupa juga diungkapkan oleh Adnan yang mengatakan bahwa La siri merupakan salah satu tokoh yang berperan penting dalam pembentukan kembali Limbo Tomoahi karena dialah yang menemui masyarakat Tomoahi di berbagai tempat pelarian dan mengajak mereka kembali dengan iming-iming berupa pembukaan lahan perkebunan kelapa yang akan dimiliki oleh orang yang menanam kelapa tersebut berapapun jumlah pohon yang ditanam akan menjadi miliknya asalkan mereka mau kembali ke Tomoahi serta akan dipindahkannya lokasi Limbo Tomoahi dari Tangkeno Tomoahi ke Epe sesuai keinginan masyarakat tomoahi di tempat pelarian (Adnan, wawancara 24 Oktober 2018).

Akibat dari perpindahan ini masyarakat Tomoahi mulai berubah mata pencahariannya yang tadinya hanya terfokus pada sektor agraris kini masyarakat mulai berpindah ke sektor maritim seperti nelayan, pelayaran dan tukang kayu (pembuat perahu). Akan tetapi sektor agraris tidak bisa di lepaskan sepenuhnya karena masyarakat Tomoahi tidak bisa mengandalkan sektor maritim sepenuhnya sebagai mata pencaharian karenanya banyak masyarakat yang melakukan dua jenis pekerjaan sekaligus yakni bertani dan nelayan Adapun kehidupan ekonomi masyarakat Limbo Tomoahi pada masa sekarang, tidak pernah terlepas dari sejarahnya yakni, belum pernah terlepas dari keadaan geografi setempat, karena mayoritas penduduknya masih banyak menjadi petani akan tetapi modelnya sudah berubah yakni sudah mulai menanam tanaman jangka panjang seperti, kelapa, jambu mete, kopi, dan juga menanam tanaman jangka pendek seperti ubi-ubian, padi dan sudah mengenal dunia pasar, untuk menjual hasil tanaman mereka sehingga menghasilkan uang. Perkembangan ini tidak terlepas dari perjalan sejarahnya pada masyarakat Limbo Tomoahi pada masa lalu. Perbedaan mekanismenya, dimana pada masa dahulu tidak menanam tanaman jangka panjang, hanya menanam tanaman jangka pendek untuk mempertahankan kelangsungan hidup mereka dan belum mengenal dunia pasar seperti halnya pada masa sekarang.

\section{KESIMPULAN}

Berdasarkan hasil penelitian tersebut dapat disimpulkan bahwa pertama Latar belakang terbentuknya Limbo Tomoahi dilihat dari beberapa faktor yaitu:(a) faktor wilayah, (b) faktor sosial budaya, (c) faktor pertanian,. Kedua Faktor terbentuknya Limbo Tomoahi dalam pemerintahan Lakino Kulisusu ialah: Proses awal pembentukan Limbo Tomoahi, dari musyawarah kepala adat dan para tokoh-tokoh masyarakat yang berinisiatif untuk membentuk sebuah Limbo karena melihat perrtumbuhan penduduk yang begitu pesat dan persyaratan pembentukan salah satu Limbo sudah sepenuhnya dimiliki oleh Tomoahi pada saat itu seperti jumlah penduduk, luas wilayah, sosial budaya dan kehidupan masyarakatnya. Sehingga tidak bisa dipungkiri, bahwasanya Limbo Tomoahi sudah layak dibentuk. Ini semua berkat antusias tokoh-tokoh masyarakat dan kepala adat serta dukungan dari Barata Kulisusu. Ketiga perkembangan Limbo Tomoahi dalam pemerintahan Lakino Kulisusu Tahun 1605-1956 secara umum menunjukan perkembangan yang lebih baik seperti Dalam bidang politik Limbo Tomoahi menunjukan pemerintahan yang sudah cukup maju seperti penyusunan hukum-hukum yang berlaku pengangkatan aparat. Dari segi bidang ekonomi masyarakat Limbo Tomoahi semakin maju ke arah kesejahteraan dengan memanfaatkan sumber daya alam dan sumber daya manusia dalam mengelola perkebunan. Dalam bidang sosial Limbo Tomoahi selalu menjunjung tinggi rasa kebersamaan dalam setiap kegiatan baik itu pembukaan lahan atau dalam upacara kematian. Selanjutnya perpindahan wilayah dari Tangkeno Tomoahi ke Epe membuat Limbo Tomoahi menjadi semakin dekat dengan pusat pemerintahan Barata Kulisusu yang membuat Limbo Tomoahi dapat berhubungan secara langsung dengan pusat pemerintahan.

\section{DAFTAR PUSTAKA}

Arifin. 1987. Gagasan Pembaharuan Muhammadyah Dalam Pendidikan. Jakarta: Dunia Pusat Jaya.

Helius Sjamsuddin. 2012. Metodologi Sejarah. Yogyakarta: Ombak.

Hugiono dan P.K Poerwantana. 1984. Pengantar Ilmu Sejarah. Jakarta: Balai Pustaka.

Kuntowijoyo. 1995. Pengantar Ilmu Sejarah. Yogyakarta: Yayasan Benteng. 
E-ISSN: 2502-6674

P-ISSN: 2502-6666

http://ojs.uho.ac.id/index.php/p_sejarah_uho

Nasution. 1998. Komunikasi Pembangunan Pengenalan Teori dan Penerapannya. Jakarta: Raja Grafindo Persada

Rahmat Hidayat. 2016. "Solidaritas Sosial Masyarakat Petani di Kelurahan Bontolerung

Kecamatan Tinggimoncong Kabupaten Gowa". Skripsi. Jurusan Sosiologi Agama, Fakultas Ushuluddin dan Filsafat, UIN, Alauddin Makassar

Ruslan Abdulgani. 1965. Sosialisme Indonesia. Jakarta: Yayasan Prapanca

Rustam E. Tamburaka. 1993. Fragmen-Fragmen, Teori-Teori, Filsafat Sejarah, Logika dan Metodologi Penelitian. Kendari: Unhalu

Sartono Kartodirdjo. 2002. Teori Sejarah dan Masalah Historiografi. Jakarta: Gramedia

Suparto. 1987. Sosiologi dan Antropologi. Bandung: CV Armico

Susanto Zuhdi. 2010. Sejarah Buton yang Terabaikan; Labu Rope-Labu Wana. PT. Raja Grafindo Pesada: Jakarta 